\title{
Aminofoszfin-oxidok, gyürüs aminofoszfonátok és rokon vegyületeik szintézise és felhasználási lehetőségei ${ }^{+}$
}

\author{
ZWILLINGER-TRIPOLSZKY Anna a, ${ }^{\mathrm{a},}$ BÁLINT Erikaa ${ }^{\mathrm{a}}$, KEGLEVICH György ${ }^{\mathrm{a}}$ \\ ${ }^{a}$ Budapesti Müszaki és Gazdaságtudományi Egyetem, Vegyészmérnöki és Biomérnöki Kar, Szerves Kémia és Technológia \\ Tanszék, Budafoki út 8. F. II. magasföldszint, 1111 Budapest, Magyarország
}

\section{Bevezetés}

Az $\alpha$-aminofoszfonátok, -foszfin-oxidok és a gyürüs aminofoszfonátnak tekinthető 1,2,3-triazolilfoszfonátok, valamint a foszfinát és foszfát rokonvegyületeik egyaránt kiemelt kutatási területet képviselnek a szerves foszforkémián belül $[1,2]$. A vegyületek széleskörü felhasználhatósága [3] és a különbözö hatásterületeken tapasztalt bioaktivitása [4] a szintézis-módszerek folyamatos fejlesztésére és a molekula-könyvtárak bővítésére ösztönzi a kutatókat.

Az aminofoszfonátok (1), bisz(foszfonometil)aminok (2) és rokon vegyületeik egyik leggyakrabban alkalmazott előállítási módja a Kabachnik-Fields-reakció (1. ábra) [5-7].

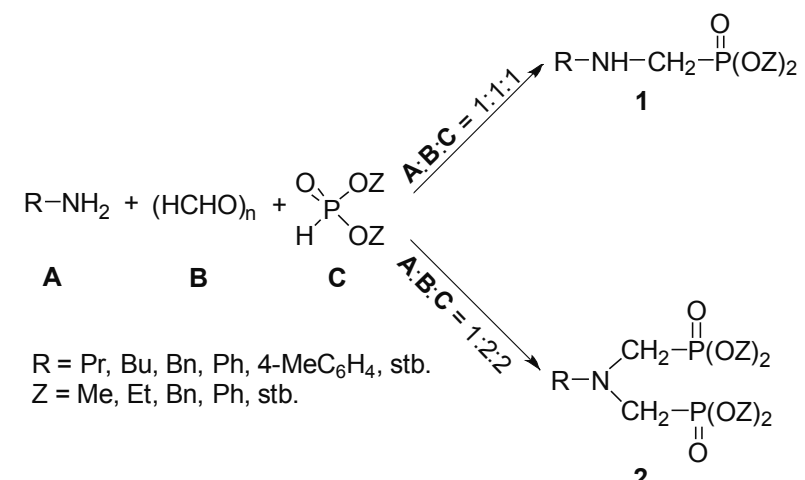

1. Ábra. Primer aminok, paraformaldehid és $>\mathrm{P}(\mathrm{O}) \mathrm{H}$ reagensek egyszeres és kétszeres Kabachnik-Fields-reakciója

A kondenzációban három komponens, egy primer amin, egy oxovegyület, valamint egy $>\mathrm{P}(\mathrm{O}) \mathrm{H}$ reagens vesz részt. A sztöchiometriai arányok megfelelő megválasztásával általában jó termeléssel és szelektíven állíthatók elő az aminofoszfonátok (1) vagy bisz(foszfonometil)aminok (2).

Az egyszeres és kétszeres Kabachnik-Fields-reakciókat az esetek nagyobb részében valamilyen adalék (katalizátor és/ vagy oldószer) jelenlétében hajtották végre [8], ugyanakkor az utóbbi évtizedekben egyre több publikáció tárgyal környezetbarát módszereket, melyekben a drága katalizátorokat és oldószereket mellőzték a szintézisek során [9-14].

Az 1,2,3-triazolilfoszfonátok és származékaik egyik kézenfekvő előállítási módja a Huisgen-féle 1,3-dipoláris azid-alkin cikloaddíció (2. ábra) [15,16]. Azidokat és foszfor-tartalmú terminális acetiléneket $\mathrm{Cu}(\mathrm{I})$-katalizátor jelenlétében, szobahőmérsékleten reagáltatva, szelektíven szintetizálhatók az 1,2,3-triazol-4-il-foszfonátok (3) [17], valamint kétszeresen szubsztituált acetilének klikk-reakciójával triszubsztituált triazol-5-il-foszfonát-származékok (4) [18].

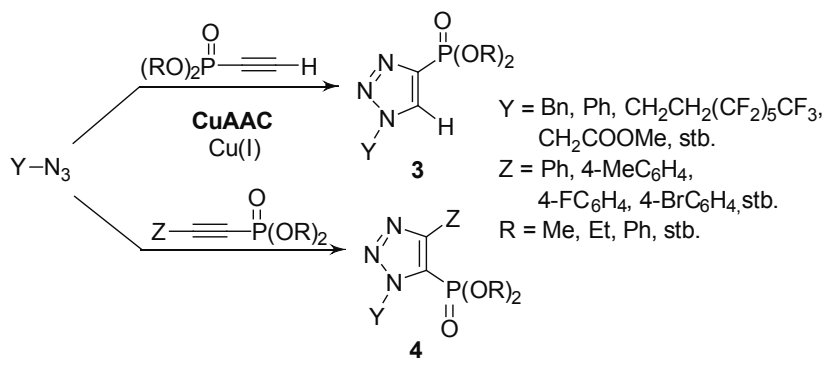

2. Ábra. 1,2,3-Triazol-4-il-foszfonátok és 1,2,3-triazol-5-il-foszfonátok előállítása 1,3-dipoláris azid-alkin cikloaddícióval

A triszubsztituált 1,2,3-triazol-5-il-foszfonátok (4) azidok, acetilének és dialkil-foszfitok $\mathrm{Cu}(\mathrm{I})$-katalizált dominó-reakciójával szintén előállíthatók (3. ábra) [19]. A háromkomponensű reakció előnye, hogy alkalmazásával elkerülhető az intermedierek izolálása.

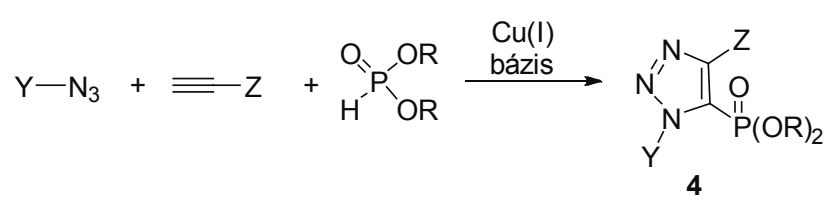

$\mathrm{Y}={ }^{n} \mathrm{C}_{6} \mathrm{H}_{13},\left(\mathrm{CH}_{2}\right)_{2} \mathrm{CH}_{2} \mathrm{OH}, \mathrm{Ph}, 4-\mathrm{MeC}_{6} \mathrm{H}_{4}, 4-\mathrm{FC}_{6} \mathrm{H}_{4}$, stb.

$\mathrm{Z}=\mathrm{Bn}, 4-\mathrm{MeOC}_{6} \mathrm{H}_{4},\left(\mathrm{CH}_{2}\right)_{2} \mathrm{C}_{6} \mathrm{H}_{5}$, stb.

$\mathrm{R}=\mathrm{Et},{ }^{i} \mathrm{Pr}, \mathrm{Bn}$

3. Ábra. Azidok, alkinek és dialkil-foszfitok dominó-reakciója

Mindezt figyelembe véve, kutatómunkánk során egyrészt célul tüztük ki új $\alpha$-aminofoszfin-oxid-származékok előállítását. A vegyületek szintézisét Kabachnik-Fieldsreakciókkal, katalizátor nélkül, mikrohullámú (MW) körülmények között kívántunk megvalósítani. Az új vegyületek preparálásán és jellemzésén túlmenően, vizsgálni kívántuk az elöállított bisz(foszfinoilmetil)-aminok foszfin-ligandumként történő hasznosíthatóságát átmenetifém-komplexek szintézisében. Továbbá tanulmányozni kívántuk gyürüs aminofoszfonátok, 1,2,3triazolilfoszfonátok, valamint

\footnotetext{
+ Zwillinger-Tripolszky Anna azonos címü PhD értekezéséhez kapcsolódó Tézisfüzet alapján készült.

* E-mail: tripolszky.anna@mail.bme.hu
} 
1,2,3-triazolil-foszfinátok és foszfátok szintézisét réz(I)-katalizált dominó-, illetve klikk-reakciókkal. Célul tűztük ki az előállított 1,2,3triazolilfoszfonátok biológiai aktivitásának feltérképezését is.

\section{Eredmények}

\section{1. $\alpha$-Aminofoszfin-oxidok és bisz(foszfinoilmetil)- aminok előállítása}

Kutatómunkánk első részében különböző primer aminok, paraformaldehid és Grignard-reakcióval előállított szekunder foszfin-oxidok [20] egyszeres és kétszeres KabachnikFields-kondenzációit tanulmányoztuk (4. ábra) [21]. A reakciókat minden esetben MW körülmények között, katalizátor nélkül valósítottuk meg. Az egyszeres és kétszeres Kabachnik-Fields-reakciók során 11 új aaminofoszfin-oxidot (5a-g és 6b-d,f) és 8 új $N, N$ bisz-(foszfinoilmetil)amint (7a-e és 8b-d) szintetizáltunk 94-96\%-os termeléssel.

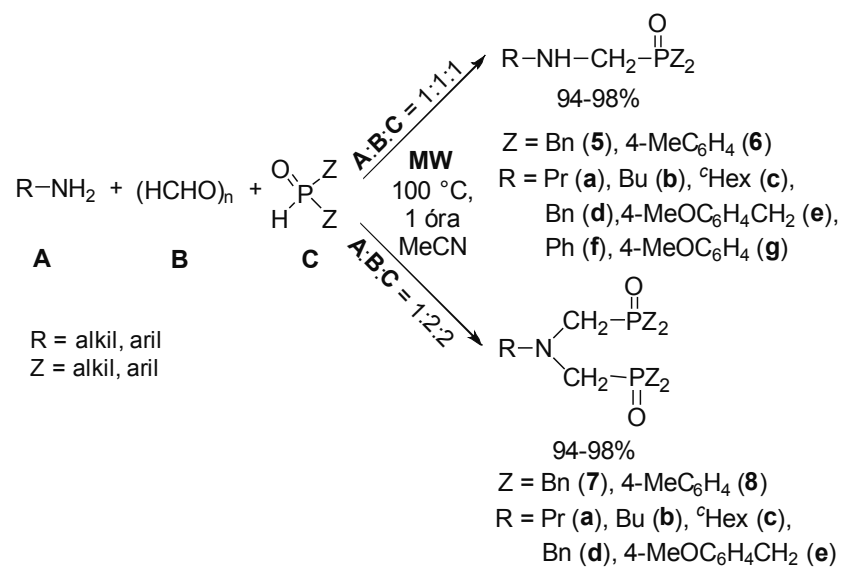

4. Ábra. Primer aminok, paraformaldehid és szekunder foszfin-oxidok egyszeres és kétszeres Kabachnik-Fields-reakciója

\subsection{A bisz(foszfinoilmetil)aminok felhasználása kétfogú foszfin-ligandumként}

Céljaink között szerepelt az előállított $N, N$ bisz(foszfinoilmetil)aminok biszfoszfin-ligandumként történő alkalmazása (5. ábra) [21]. A vegyületek kétszeres deoxigénezésének optimalizálását követően, a bisz-foszfinokat borán- és platina-komplexek szintézisében hasznosítottuk. Megvalósítottuk új borán- (9d és 10d) és új gyürüs platina-komplexek (11b-d és $\mathbf{1 2 b - d})$ előállítását. Három platinaszármazék szerkezetét röntgendiffrakciós vizsgálattal, valamint kvantumkémia számításokkal is alátámasztottuk

Az előállított Pt-komplexek (11b-d és 12b-d) katalitikus aktivitását együttmüködő partnereink sztirol hidroformilezési reakciójában tesztelték. Az általunk előállított Pt-komplexek közül a [bisz[di(p-tolil)foszfonometil]-származékok (12b-d) bizonyultak hatékonyabbnak. A kísérletek során magas konverziót és kemoszelektivitást értünk el, valamint a megszokottól eltérő regioszelektivitást tapasztaltunk, ugyanis a reakciók során minden esetben az elágazó láncú aldehid keletkezett nagyobb arányban.

\section{3. $N, N$-bisz- és $N, N, N$-trisz(foszfinoilmetil)aminok szintézise $\alpha$-aminofoszfin-oxidokból kiindulva}

Munkánk folytatásaként hatékony, katalizátormentes eljárást dolgoztunk ki a foszforatomjaikon azonos vagy különböző szubsztituenseket hordozó bisz(foszfinoilmetil)-alkilaminok (13b-d és 14b-d), bisz(foszfinoilmetil) aminok (13h, 14h és 15h) és trisz(foszfinoilmetil)aminok (16-19) előállítására (6. ábra) [22]. Összesen 13 új származék szintézisét valósítottuk meg egymást követő Kabachnik-Fields-reakciókkal.

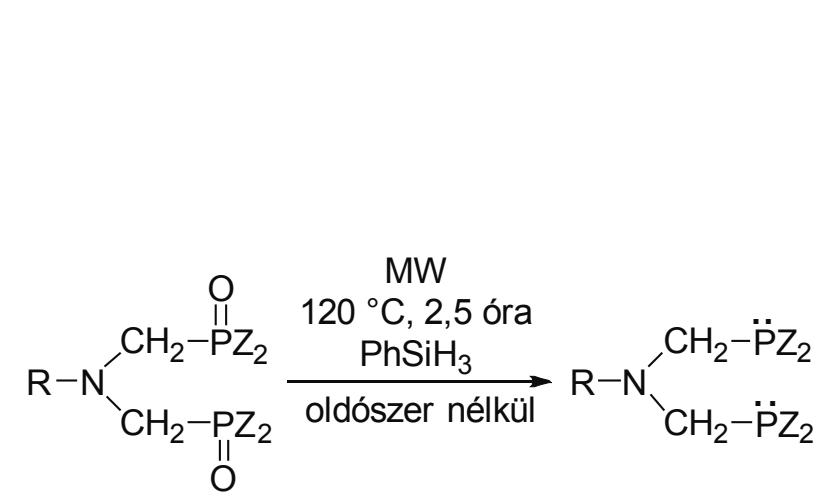

$$
\begin{aligned}
& \mathrm{Z}=\mathrm{Bn}(7), 4-\mathrm{MeC}_{6} \mathrm{H}_{4} \text { (8) } \\
& \mathrm{R}=\mathrm{Bu}(\mathbf{b}),{ }^{c} \operatorname{Hex}(\mathbf{c}), \mathrm{Bn}(\mathbf{d})
\end{aligned}
$$
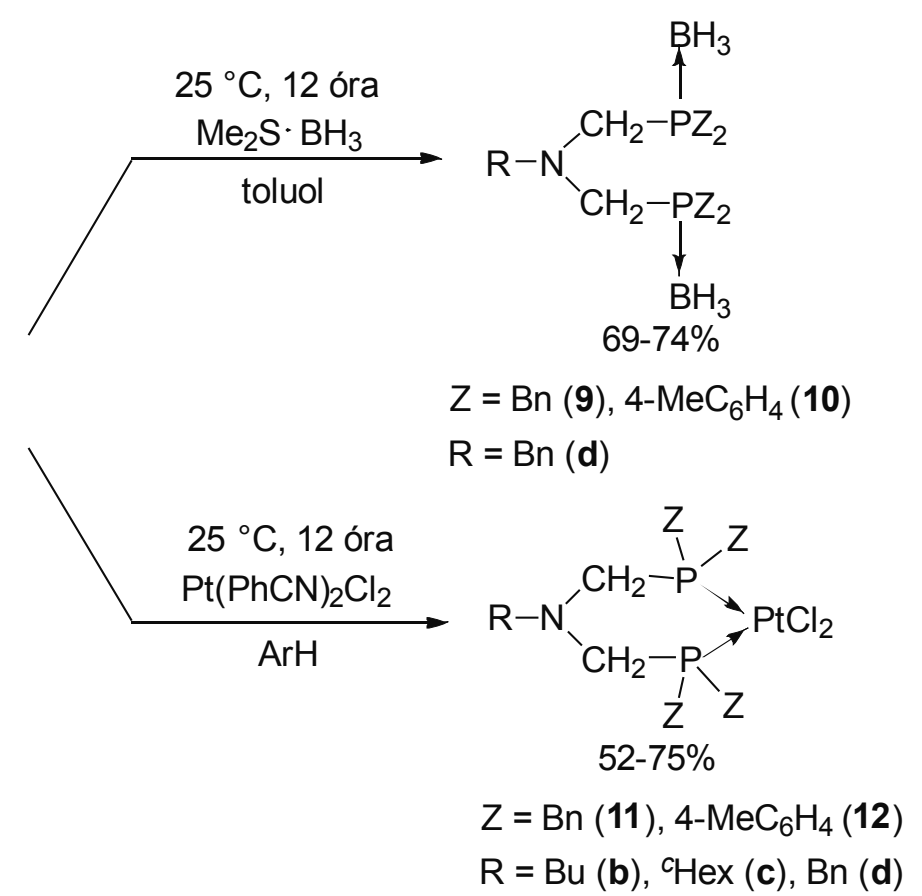

5. Ábra. Primer aminok, paraformaldehid és szekunder foszfin-oxidok egyszeres és kétszeres Kabachnik-Fields-reakciója 


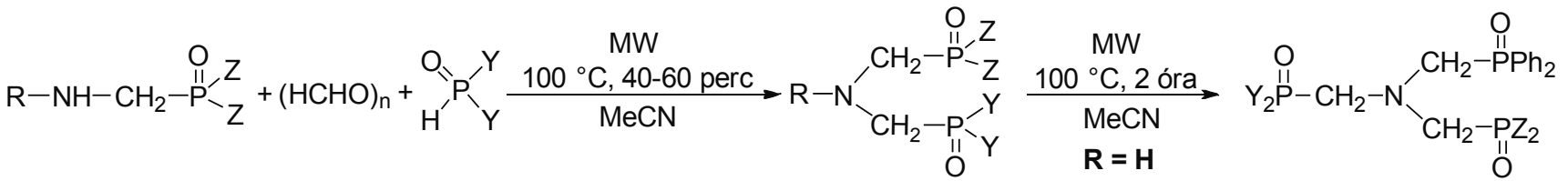

$$
\begin{aligned}
& 92-98 \% \\
& \begin{array}{c|c|c|l}
\mathrm{Z} & \mathrm{Bn} & 4-\mathrm{MeC}_{6} \mathrm{H}_{4} & \mathrm{Ph} \\
\hline \mathrm{Y} & \mathrm{Ph} & \mathrm{Ph} & \mathrm{Ph} \\
\hline & 13 & 14 & 15
\end{array} \\
& \mathrm{R}=\mathrm{Bu}(\mathbf{b}),{ }^{C} \mathrm{Hex}(\mathbf{c}), \mathrm{Bn}(\mathbf{d}), \mathrm{H}(\mathbf{h})
\end{aligned}
$$

6. Ábra. Bisz(foszfinoilmetil)aminok és trisz(foszfinoilmetil)aminok szintézise

\subsection{Acilaminofoszfin-oxidok előállítása}

Bizonyítottuk, hogy a Kabachnik-Fields-kondenzáció a primer aminokhoz képest kisebb reakcióképességgel rendelkező amidokra is kiterjeszthető (7. ábra) [23]. A reakciókat MW reaktorban kivitelezve, az amidokat feleslegben - oldószerként is - alkalmazva, valósítottuk meg az acilezett aaminofoszfin-oxidok előállítását. A kondenzációt három különbözö amiddal, paraformaldehiddel és szekunder foszfin-oxidokkal elvégezve - változó termeléssel - összesen 12 új acilaminofoszfin-oxidot (20a-c, 21a-c, 22a-c és 23a-c) szintetizáltunk.

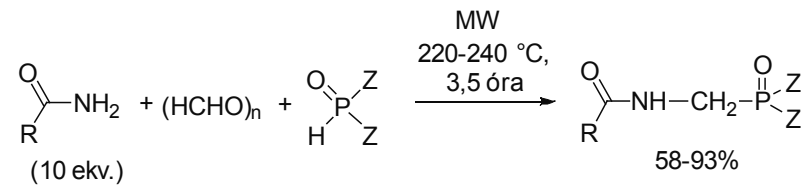

$$
\begin{aligned}
& \mathrm{Z}=\mathrm{Bn}(20), \mathrm{Ph} \text { (21), } \\
& \text { 4- } \mathrm{MeC}_{6} \mathrm{H}_{4} \text { (22), } \\
& \text { 3,5- } \mathrm{Me}_{2} \mathrm{C}_{6} \mathrm{H}_{3} \text { (23) } \\
& \mathrm{R}=\mathrm{Me}(\mathbf{a}), \mathrm{Et}(\mathbf{b}), \mathrm{Ph}(\mathbf{c})
\end{aligned}
$$

7. Ábra. Amidok, paraformaldehid és szekunder foszfin-oxidok Kabachnik-Fields-reakciója

\subsection{1,2,3-Triazol-5-il-foszfonátok előállítása dominó- reakcióval}

Kutatómunkánk következő fázisában vizsgáltuk gyürüs aminofoszfonátok és származékaik elöállítási lehetőségeit. Fenil-acetilén, benzil-azid és dibutil-foszfit modellreakcióján keresztül optimalizáltuk a $\mathrm{Cu}(\mathrm{I})$-katalizált dominó-reakciót. A reakciót különböző szerves azidokkal és dialkil-foszfitokkal végrehajtva 17 gyürüs aminofoszfonátot (24a-f, 25a,b,e, 26e, 27e, 28e, 29e, 30a,b,e és 31e) szintetizáltunk, melyek közül 15 új származék (8. ábra) [24].

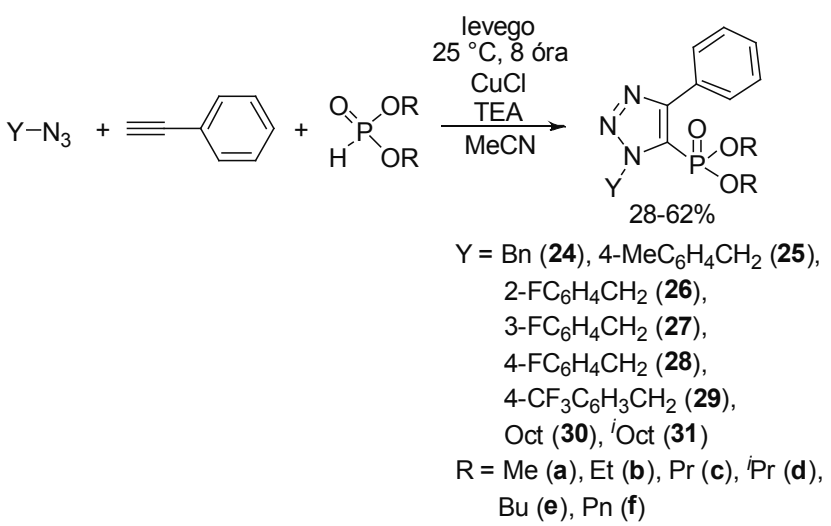

8. Ábra. Triazol-5-il-foszfonátok előállítása dominó-reakcióval

\section{6.(1,2,3-Triazol-4-il)metilfoszfinátok és -foszfátok szintézise klikk-reakcióval}

A gyürűs aminofoszfonátok elöállítását követően, célul tűztük ki a 4-es helyzetben foszfortartalmú oldalláncot tartalmazó triazolok szintézisét is. A kívánt vegyületekhez az észteresítéssel könnyen elöállítható propinilfoszfinát, valamint propinilfoszfát és szerves azidok $\mathrm{Cu}(\mathrm{I})$-katalizált klikk-reakciójával jutottunk (9. ábra) [25]. A klikk-reakció optimalizálását követően, a cikloaddíció kiterjesztése során 20 új (1,2,3-triazol-4-il)metilfoszfinát (32a-j) és -foszfát (33a-j) szintézisét valósítottuk meg.

$$
\begin{aligned}
& 60{ }^{\circ} \mathrm{C}, 10-30 \text { perc } \\
& \mathrm{CuSO}_{4} \cdot 5 \mathrm{H}_{2} \mathrm{O}
\end{aligned}
$$

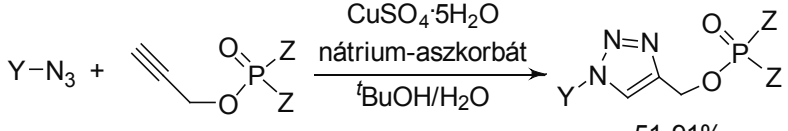

$$
\begin{aligned}
& 51-91 \% \\
& \mathrm{Z}=\mathrm{Ph} \text { (32), OEt (33) } \\
& \mathrm{Y}=\mathrm{Bn}(\mathbf{a}), 4-\mathrm{MeC}_{6} \mathrm{H}_{4} \mathrm{CH}_{2}(\mathbf{b}) \text {, } \\
& \text { 2- } \mathrm{FC}_{6} \mathrm{H}_{4} \mathrm{CH}_{2} \text { (c), 3- }-\mathrm{FC}_{6} \mathrm{H}_{4} \mathrm{CH}_{2} \text { (d), } \\
& \text { 4- } \mathrm{FC}_{6} \mathrm{H}_{4} \mathrm{CH}_{2}(\mathrm{e}) \text {, } \\
& \text { 4- } \mathrm{CF}_{3} \mathrm{C}_{6} \mathrm{H}_{3} \mathrm{CH}_{2}(\mathbf{f}) \text {, Oct (g), } \\
& { }^{i} \mathrm{Oct}(\mathbf{h}),{ }^{c} \mathrm{Hex}(\mathbf{i}), \mathrm{Ph}(\mathbf{j})
\end{aligned}
$$

9. Ábra. (1,2,3-Triazol-4-il)metilfoszfinát- és -foszfát-származékok elóállítása 
2.7. Az 1,2,3-triazol-5-il-foszfonátok antibakteriális aktivitás és in vitro citotoxicitás vizsgálata

Együttműködő partnereink segítségével meghatároztuk az elöállított 1,2,3-triazol-5-il-foszfonátok antibakteriális hatását Gram-pozitív (Bacillus subtilis) és Gram-negatív (Escherichia coli) baktériumsejtekkel szemben, továbbá a vegyületek in vitro citotoxicitását is vizsgáltuk három különféle sejtvonalon (1. Táblázat) [25]. Az 1,2,3triazolilfoszfonátok enyhe antibakteriális hatással rendelkeztek az érzékenyebb Bacillus subtilis baktériumsejtekkel szemben, valamint több származék (24c, 24e, 24f, 25a, 26e, 27e, 28e, 29e és 30e) aktivitást mutatott egér fibroblaszt (NIH/3T3) és humán mieloid leukémia (HL-60) sejtvonalakon.<smiles>[R]OP(O)c1c(-c2ccccc2)nnn1[Y]</smiles>

\begin{tabular}{|c|c|c|c|c|c|c|c|}
\hline \multirow[t]{2}{*}{ Vegyület } & \multirow[t]{2}{*}{$\mathbf{Y}$} & & \multirow{2}{*}{$\begin{array}{c}\text { R } \\
\text { B. subtilis }\end{array}$} & \multicolumn{2}{|c|}{$\begin{array}{l}\text { Antibakteriális hatás } \\
\text { (IC50, } \mu \mathrm{M})\end{array}$} & \multicolumn{2}{|c|}{ In vitro citotoxicitás (IC50, $\mu \mathrm{M})$} \\
\hline & & & & E. coli & A549 & NIH/3T3 & HL-60 \\
\hline $24 a$ & $\mathrm{Bn}$ & $\mathrm{Me}$ & $>30$ & $>30$ & $>30$ & $>30$ & $>30$ \\
\hline $24 b$ & $\mathrm{Bn}$ & $\mathrm{Et}$ & $>30$ & $>30$ & $>30$ & $>30$ & $>30$ \\
\hline $24 c$ & $\mathrm{Bn}$ & $\operatorname{Pr}$ & $29.3 \pm 1.2$ & $>30$ & $>30$ & $>30$ & $12.6 \pm 1.7$ \\
\hline 24d & $\mathrm{Bn}$ & ${ }^{i} \operatorname{Pr}$ & $>30$ & $>30$ & $>30$ & $>30$ & $>30$ \\
\hline $24 \mathrm{e}$ & $\mathrm{Bn}$ & $\mathrm{Bu}$ & $>30$ & $>30$ & $>30$ & $27.5 \pm 1.4$ & $>30$ \\
\hline $24 f$ & $\mathrm{Bn}$ & $\mathrm{Pn}$ & $23.9 \pm 1.0$ & $>30$ & $>30$ & $26.2 \pm 1.1$ & $15.4 \pm 1.2$ \\
\hline $25 \mathrm{a}$ & $4-\mathrm{MeC}_{6} \mathrm{H}_{4}$ & $\mathrm{Me}$ & $>30$ & $>30$ & $>30$ & $19.8 \pm 1.2$ & $11.0 \pm 1.2$ \\
\hline $25 b$ & $4-\mathrm{MeC}_{6} \mathrm{H}_{4}$ & Et & $>30$ & $>30$ & $>30$ & $>30$ & $>30$ \\
\hline $25 \mathrm{e}$ & $4-\mathrm{MeC}_{6} \mathrm{H}_{4}$ & $\mathrm{Bu}$ & $18.2 \pm 1.0$ & $>30$ & $>30$ & $>30$ & $>30$ \\
\hline $26 \mathrm{e}$ & $2-\mathrm{FC}_{6} \mathrm{H}_{4}$ & $\mathrm{Bu}$ & $19.3 \pm 1.0$ & $>30$ & $>30$ & $27.5 \pm 1.1$ & $11.7 \pm 1.2$ \\
\hline $27 \mathrm{e}$ & $3-\mathrm{FC}_{6} \mathrm{H}_{4}$ & $\mathrm{Bu}$ & $>30$ & $>30$ & $>30$ & $>30$ & $15.4 \pm 1.2$ \\
\hline $28 \mathrm{e}$ & $4-\mathrm{FC}_{6} \mathrm{H}_{4}$ & $\mathrm{Bu}$ & $23.2 \pm 1.1$ & $>30$ & $>30$ & $>30$ & $16.6 \pm 1.3$ \\
\hline $29 \mathrm{e}$ & $4-\mathrm{CF}_{3} \mathrm{C}_{6} \mathrm{H}_{4}$ & $\mathrm{Bu}$ & $>30$ & $>30$ & $>30$ & $23.1 \pm 1.2$ & $9.7 \pm 1.1$ \\
\hline 30a & Oct & $\mathrm{Me}$ & $>30$ & $>30$ & $>30$ & $>30$ & $>30$ \\
\hline $30 \mathrm{~b}$ & Oct & $\mathrm{Et}$ & $>30$ & $>30$ & $>30$ & $>30$ & $>30$ \\
\hline $30 \mathrm{e}$ & Oct & $\mathrm{Bu}$ & $>30$ & $>30$ & $>30$ & $>30$ & $>30$ \\
\hline 31e & ${ }^{i}$ Oct & $\mathrm{Bu}$ & $29.6 \pm 1.0$ & $>30$ & $>30$ & $>30$ & $26.7 \pm 1.0$ \\
\hline & Doxiciklin & & $0.04 \pm 0.01$ & $0.10 \pm 0.02$ & - & - & - \\
\hline & Gentamicin & & $0.49 \pm 0.14$ & $4.23 \pm 0.99$ & - & - & - \\
\hline & Doxorubicin & & - & - & $0.31 \pm 0.24$ & $5.65 \pm 0.81$ & - \\
\hline & Bortezomib & & - & - & - & - & $7.4210^{-3} \pm 2.601^{0-3}$ \\
\hline
\end{tabular}

1. Táblázat. Az 1,2,3-triazol-5-il-foszfonátok antibakteriális aktivitás és in vitro citotoxicitás vizsgálatainak eredményei és azok szórása

\section{Összefoglalás}

Összességében elmondható, hogy a célul kitüzött új $\alpha$ aminofoszfin-oxidok (5a-g, 6b-d,f, 20a-c, 21a-c, 22a-c és 23a-c), bisz(foszfinoilmetil)aminok (7a-e, 8b-d, 13b-d,h, 14b-d,h és 15h) és trisz(foszfinoilmetil)aminok (16-19) elöállítását hatékonyan megvalósítottuk. A vegyületek szintézisét MW besugárzással elősegített egyszeres, kétszeres és több lépésben elvégzett Kabachnik-Fields-reakciókkal hajtottuk végre. A bisz(foszfinoilmetil)-aminokat (7b-d és 8b- d) kettős deoxigénezést követően biszfoszfin-ligandumként hasznosítottuk borán- (9d, 10d) és platina-komplexek (11bd, 12b-d) szintézisében. Elvégeztük gyürüs aminofoszfonátok, 1,2,3triazolilfoszfonátok (24a-f, 25a,b,e, 26e, 27e, 28e, 29e, 30a,b,e és 31e), valamint (1,2,3triazol-4-il)metilfoszfinátok (32a-j) és -foszfátok (33a-j) előállítását réz(I)katalizált dominó- és klikk-reakciókkal. A témában végzett kutatómunkánk során közel 100 új vegyülettel bővítettük az aminofoszfin-oxid-származékok és a gyürüs aminofoszfonátok, illetve rokon vegyületeik vegyület-családjait. 


\section{Köszönetnyilvánítás}

A B.E. és T.A. köszönetét fejezik ki a Nemzeti Kutatási, Fejlesztési és Innovációs Hivatal (FK123961), valamint az Új Nemzeti Kiválóság Program (ÚNKP-19-3-I-BME-391) anyagi támogatásáért.

\section{Hivatkozások}

1. Hudson, H. R.; Kukhar, V. P. Aminophosphonic and aminophosphinic acids: chemistry and biological activity; Wiley: Chichester, 2000. ISBN 0-471-89149-5

2. Moonen, K.; Laureyn, I.; Stevens, C. V. Chem. Rev. 2004, 104, 6177-6215. https://doi.org/10.1021/cr030451c

3. Shartri, R.A Chem. Sci. Trans. 2019, 8, 359-367. https://doi.org/10.7598/cst2019.1585

4. Tajti, Á.; Keglevich, G. The importance of organophosphorus compounds as biologically active agents. In: Organophosphorus Chemistry; Keglevich, G. (ed.); Walter de Gruyter: Berlin, 2018, pp. 53-65 ISBN 978-3-11-053583-9 https://doi.org/10.1515/9783110535839-003

5. Kabachnik, M. I.; Medved, T. Y. Dokl. Akad. Nauk. SSSR 1952. 689. Chem. Abstr. 1953, 47, $2724 \mathrm{~b}$.

6. Fields, E. K. J. Am. Chem. Soc. 1952, 74, 1528-1531. https://doi.org/10.1021/ja01126a054

7. Keglevich, G.; Bálint, E. Molecules 2012, 17, 12821-12835. https://doi.org/10.3390/molecules171112821

8. Zefirov, N. S.; Matveeva, E. D. Arkivoc 2008, 2008, 1-17. https://doi.org/10.3998/ark.5550190.0009.101

9. Kafarski, P.; Gorny vel Gorniak, M.; Andrasiak, I. Curr. Green Chem. 2015, 2, 218-222. https://doi.org/10.2174/2213346102666150109203606

10. Keglevich, G.; Szekrényi, A. Lett. Org. Chem. 2008, 5, 616-622. https://doi.org/10.2174/157017808786857598

11. Tajti, Á.; Bálint, E.; Keglevich, G. Curr. Org. Synth. 2015, $13,638-645$. https://doi.org/10.2174/1570179413666151218202757

12. Bálint, E.; Tóth, R. E.; Keglevich, G. Heteroat. Chem. 2016, $27,323-335$. https://doi.org/10.1002/hc. 21343
13. Bálint, E.; Takács, J.; Drahos, L.;Juranovič, A.; Kočevar, M.; Keglevich, G. Heteroat. Chem. 2013, 24, 221-225. https://doi.org/10.1002/hc. 21086

14. Bálint, E.; Tajti, Á.; Kalocsai, D.; Mátravölgyi, B.; Karaghiosoff, K.; Czugler, M.; Keglevich, G. Tetrahedron 2017, 73, 5659-5667. https://doi.org/10.1016/j.tet.2017.07.060

15. Rostovtsev, V. V.; Green, L. G.; Fokin, V. V.; Sharpless, K. B. Angew. Chemie - Int. Ed. 2002, 41, 2596-2599. https://doi.org/10.1002/1521-3773(20020715)41:14<2596:: AID-ANIE2596 $>3.0 . \mathrm{CO} ; 2-4$

16. Tornøe, C. W.; Christensen, C.; Meldal, M. J. Org. Chem. 2002, 67, 3057-3064. https://doi.org/10.1021/jo011148j

17. Mukai, S.; Flematti, G. R.; Byrne, L. T.; Besant, P. G.; Attwood, P. V.; Piggott, M. J. Amino Acids 2012, 43, 857-874. https://doi.org/10.1007/s00726-011-1145-2

18. Huang, P.; Su, Q.; Dong, W.; Zhang, Y.; An, D. Tetrahedron 2017, 73, 4275-4284. https://doi.org/10.1016/j.tet.2017.05.076

19. Li, L.; Hao, G.; Zhu, A.; Fan, X.; Zhang, G.; Zhang, L. Chem. - A Eur. J. 2013, 19, 14403-14406. https://doi.org/10.1002/chem.201303324

20. Tripolszky, A.; Keglevich, G. Lett. Org. Chem. 2018, 15, 387-393. https://doi.org/10.2174/1570178615666171227144555

21. Bálint, E.; Tripolszky, A.; Jablonkai, E.; Karaghiosoff, K.; Czugler, M.; Mucsi, Z.; Kollár, L.; Pongrácz, P.; Keglevich, G. J. Organomet. Chem. 2016, 801, 111-121. https://doi.org/10.1016/j.jorganchem.2015.10.029

22. Bálint, E.; Tripolszky, A.; Hegedűs, L.; Keglevich, G. Beilstein J. Org. Chem. 2019, 15, 469-473. https://doi.org/10.3762/bjoc. 15.40

23. Tripolszky, A.; Zoboki, L.; Bálint, E.; Kóti, J.; Keglevich, G. Synth. Commun. 2019, 49, 1047-1054. https://doi.org/10.1080/00397911.2019.1584675

24. Tripolszky, A.; Tóth, E.; Szabó, P. T.; Hackler, L.; Kari, B.; Puskás, L. G.; Bálint, E. Molecules 2020, 25, 2643. https://doi.org/10.3390/molecules25112643

25. Tripolszky, A.; Németh, K.; Szabó, P. T.; Bálint, E. Molecules 2019, 24, 2085. https://doi.org/10.3390/molecules24112085 


\section{Synthesis and utilization of aminophospine oxides, cyclic aminophosphonates and their related compounds}

$\alpha$-Aminophosphonates, aminophosphine oxides and cyclic aminophosphonates, 1,2,3triazolylphosphonates, as well as their phosphinate and phosphate related derivatives have received an intensively growing interest within organic phosphorus chemistry $[1,2]$. The widespread applicability [3] and the versatile bioactivity [4] of the compounds encourage researchers to develop synthetic methods and expand molecule libraries continuously.

One of the most convenient and widespread methods for the synthesis of $\alpha$-aminophosphonates (1) and bis(phosphonomethyl) amines is the Kabachik-Fields, or so called phospha-Mannich reaction (Fig. 1.) [5-7]. This reaction is based on the condensation of an amine, an aldehyde and a $>\mathrm{P}(\mathrm{O}) \mathrm{H}$ species. Aminophosphonates (1) or bis(phosphonomethyl)amines (2) can be prepared selectively, and generally in good yields by changing the stoichiometric ratios properly.

Since the discovery of the reaction, most of the papers were on cases utilizing catalyst and/or solvent [8]. However, in recent decades, an increasing number of publications discuss environmentally friendly methods without expensive catalysts and solvents [9-14].

One of the most effective tools for the preparation of 1,2,3triazolylphosphonates and their derivatives is the Huisgen's 1,3dipolar azide-alkyne cycloaddition (Fig. 2) [15,16]. 1,2,3-Triazol4-ylphosphonates (3) can be selectively synthesized by the $\mathrm{Cu}(\mathrm{I})$-catalyzed reaction of azides and phosphorus-containing terminal acetylenes at room temperature [17]. Trisubstituted triazol-5-ylphosphonate derivatives (4) can be prepared by the click reaction of azides and internal acetylenes [18].

Trisubstituted 1,2,3-triazol-5-ylphosphonates (4) can also be prepared by $\mathrm{Cu}(\mathrm{I})$-catalyzed domino reactions of azides, acetylenes, and dialkyl phosphites (Fig. 3) [19]. One of the many advantages of the three-component reaction is that it avoids the isolation of intermediates, and thus has the ability to save time and energy and being environmentally friendly.

The aim of our research work was to synthesize new aaminophosphine oxides and 1,2,3triazolylphosphonates, as cyclic $\alpha$-aminophosphonates, and other derivatives. The aminophosphine oxides and their derivatives were synthesized by KabachnikFields reactions. In addition to the preparation and characterization of the new compounds, we wished to investigate the utility of the prepared bis(phosphinoylmethyl) amines as phosphine ligands in the synthesis of transition metal complexes. The synthesis of cyclic aminophosphonates, 1,2,3triazolylphosphonates, 1,2,3-triazolylphosphinates and phosphates was studied by copper(I)-catalyzed domino and click reactions. The biological activity of the 1,2,3triazolyl-phosphonates prepared was examined.

Considering the aspects of green chemistry, the aaminophosphine oxides (5a-g and $\mathbf{6 b - d , f )}$ and bis(phosphinoylmethyl)amines (7ae and $\mathbf{8 b - d}$ ) were synthesized by the microwave-assisted and cat- alyst-free single and double Kabachnik-Fields reactions (Fig. 4.) [21]. After double deoxygenation, the bis(phosphinoyl-methyl) amines (7b-d and $\mathbf{8 b - d}$ ) were utilized in the preparation of boron (9d, 10d) and cyclic platinum complexes (11b-d and 12b-d) (Fig. 5.). In the hydroformylation of styrene high conversion, chemoselectivity, and an unusual regioselectivity toward branched aldehyde were observed using the platinum complexes synthesized (11b-d and 12b-d).

As a continuation of our work, we have developed an efficient, catalyst-free process for the synthesis of bis(phosphinoylmethyl) amines (13b-d, 14b-d, 13h, $\mathbf{1 4 h}$ and $\mathbf{1 5 h}$ ), as well as tris(phosphinoyl-methyl)amines (16-19) bearing identical or different substituents on their phosphorus atoms (Fig. 6.) [22].

The Kabachnik-Fields condensation was extended to amides that have a considerably lower reactivity than primary amines (Fig. 7.) [23]. The reactions were carried out in a MW reactor, using the amides in excess to afford the new acylaminophosphine oxides (20a-c, 21a-c, 22a-c) with good yields.

In the next part, we elaborated the synthesis of cyclic aminophosphonates, 1,2,3-triazolylphosphonates (24a-f, 25a,b,e, 26e, 27e, 28e, 29e, 30a,b,e and 31e), (1,2,3-triazol-4-yl)methylphosphinates (32a-j) and -phosphates (33a-j). The synthesis of cyclic aminophosphonates, 1,2,3triazolylphosphonates (24a-f, 25a,b,e, 26e, 27e, 28e, 29e, 30a,b,e and 31e) was investigated by the copper(I)-catalyzed domino reaction of organic azides, phenylacetylene and dialkyl phosphites (Fig. 8.) [24]. The (1,2,3-triazol-4-yl) methylphosphinates (32a-j) and phosphates $(\mathbf{3 3} \mathbf{a}-\mathbf{j})$ were prepared by the copper(I)-catalyzed click reaction of organic azides and prop-2-ynyl diphenylphosphinate or diethylprop-2-ynyl phosphate (Fig. 9.) [25].

The antibacterial activity of the synthesized 1,2,3-triazol-5-yl-phosphonates (24a-f, 25a,b,e, 26e, 27e, 28e, 29e, $\mathbf{3 0 a}, \mathbf{b}, \mathbf{e}$ and $\mathbf{3 1 e}$ ) was tested, and in vitro cytotoxicity assays were performed on three different cell lines.

To summarize, the targeted new $\alpha$-aminophosphine oxides (5ag, 6a-g, 20a-c, 21a-c, 22a-c and 23a-c), bis(phosphinoylmethyl) amines (7b-e, 8b-e, 13b-d, h, 14b-d, h and 15h) and tris(phosphinoylmethyl)amines (16-19) were successfully prepared. The synthesis of the compounds was performed by single, double, and multi-step Kabachnik-Fields reactions under MW irradiation. After double deoxygenation, bis(phosphinoylmethyl) amines (7b-d and 8b-d) were successfully utilized as bisphosphine ligands in the synthesis of borane (9d, 10d) and platinum complexes (11b-d, 12b-d). Cyclic aminophosphonates, 1,2,3-triazolylphosphonates (24a-f, 25a,b,e, 26e, 27e, 28e, 29e, 30a,b,e and 31e) and (1,2,3-triazol-4-yl)methyl-phosphinates (32a-j) and -phosphates (33a-j) were synthesized by copper(I)-catalyzed domino and click reactions. In the course of our research work, we have expanded the family of aminophosphine oxide derivatives and cyclic aminophosphonates and their related compounds with nearly 100 new compounds. 